$\left(\begin{array}{ccr}\text { Jpn. J.Hosp. } & \text { Pharm. } \\ \hdashline & \text { 般 } & \text { 論 } \\ 233 & 189-193 & (1997)\end{array}\right)$

\title{
キトサン表面処理綿の薬物吸着特性
}

梶本晴彦*, 綾田直美

株式会社カナエ開発部†

\section{Drug Adsorption of Cotton Coated with Chitosan}

\author{
HARUHIKO KAJIMOTO*, NAOMI AYADA
}

Research and Development Department, Kanae Co., Ltd. $\dagger$

$\left(\begin{array}{l}\text { Received September 13, } 1996 \\ \text { Accepted January 29, } 1997\end{array}\right)$

Topical medicinal substances (or drugs) in liquid formulations are conventionally applied using cotton, gauze or other applicators made of cellulose materials. The adsorption of drugs by these cellulose materials is known to reduce the availability and, therefore, the efficacy of such drugs for patient treatment. In our previous studies, cellulose fibers were found to be negatively charged. A substantial degree of adsorption of positively charged or cationic drugs, such as disinfectants, due to electrostatic interaction was also observed in these studies. The objective of this study was thus to determine the effect of coating cotton with positively charged chitosan on cationic drug adsorption. The results of this study indicate that coating cotton with chitosan reduces the adsorption of cationic drugs in the application of topical formulations.

Key words - adsorption, cotton, gauze, $\zeta$-potential, chitosan

\section{緒言}

外用液剤を使用する際, 日局脱脂綿, 日局ガー ゼおよびセルロース系不織布等のセルロース系繊 維を担体としてこれに含浸し, 適用部位に塗布す ることが多いが，この場合これら担体への薬物の 吸着が問題となる ${ }^{1.2)}$.

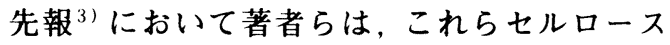
系繊維は漂白工程等による酸化により生じると考 えられる $\mathrm{COO}^{-} に$ 起因する負のゼータ電位を有

† 大阪市旭区高殿 4-16-11；4-16-11,Takadono, Asahi-ku, Osaka, 535 Japan
し 4-6)，アニオン性薬物および非イオン性薬物に 比べてカチオン性薬物の吸着量が著しいことを認 めた.さらに電気的相互作用力がセルロース系繊 維と薬物の吸着に大きく作用していることを確認 すると共に, 塩の添加および $\mathrm{pH}$ の酸性側への調 整がカチオン性薬物の吸着防止に有効であること を報告した。

本報では特に外用消毒荗に多いカチオン性薬物 のセルロース系繊維への吸着を抑える目的でカ 二,エビ等に含まれるキチンの脱アセチル化物 で, 塩基性多糖体であるキトサンをセルロース系 繊維表面に吸着処理し, 正のゼータ電位を付与す 
ることを考えた。キトサンは分子内に遊離のアミ ノ基を有することから正のゼータ電位を有する. このキトサンを負のゼータ電位を示すセルロース 系繊維に吸着処理することにより, 繊維の電位を 正電位側に調整した。

\section{実 験 の 部}

\section{1. 材料}

1) 担体および表面処理剛

担体として日局脱脂綿を使用した。表面処理剤 としてキトサン (chitosan PSH, 焼津水産化学工 業 (静岡)）を使用した。

\section{2 ) 薬物}

カチオン性モデル薬物としてグルコン酸クロル ヘキシジン液, 塩化ベンザルコニウム, 塩酸ジブ カイン，アニオン性モデル薬物としてサリチル 酸, 非イオン性モデル薬物としてパラオキシ安息 香酸メチルを使用した。

これらはいずれも日本薬局方収載品を使用し た.

\section{2. キトサン表面処理綿の調製}

キトサンを酢酸酸性で溶解した溶液中に脱脂綿 を浸漬し， 2 時間放置後水洗し， $80^{\circ} \mathrm{C} て ゙ 2$ 時間乾 燥してキトサン表面処理綿を製した。なお，表面 処理量は溶液中のキトサン濃度を調節することに より変えた。

\section{3. 表面処理量の測定}

キトサンの分子構造に含まれる窒素を日局窒素 測定法により測定し, キトサン表面処理綿中の窒 素量を重量百分率で求めて表面処理量とした。表 面処理量は 3 回の平均值で示した。

\section{4 . 吸水量の測定}

日局脱脂綿の規格に示されている吸水量の試験 方法により, 綿 $5 \mathrm{~g}$ 当たりの吸水量を 6 回測定し 平均值で示した。

\section{5. ゼータ電位測定法}

流動電位測定装置 ZP-10型（島津製作所 (京都) 製）を用い, 流動電位法により行った。ゼータ電 位は 3 回の平均值で示した.

\section{6. 吸着試験方法}

\section{1) 試料溶液の調製}

グルコン酸クロルヘキシジン液, 塩化ベンザル コニウム, 塩酸ジブカインは精製水に所定の濃度 になるように溶解して試料溶液とした。サリチル 酸, パラオキシ安息香酸メチルは水に溶けにくい ため, $10 \%$ エタノール水溶液で所定の濃度になる ように溶解して試料溶液とした。

\section{2 ）吸着試験}

担体 $1 \mathrm{~g}$ をガラス製容器に入れ, $5 \mathrm{ml}$ の試料溶 液を加えて均一に含浸し, 室温 $\left(20.0 \pm 2.0^{\circ} \mathrm{C}\right)$ で十分に吸着が平衡に達する時間（30分）静置し た後，ただちにガラス製注射筒の筒内に挿入し， 注射筒の吸子で強く圧縮することにより試料溶液 を絞り出し, 絞り液の薬物濃度を高速液体クロマ トグラフ法により測定し, 同様に測定した試料溶 液の薬物濃度から次式により回収率を算出した。 回収率は 3 回測定し, 平均値を用いた。

回収率 $(\%)=\left(\mathrm{C}_{1} / \mathrm{C}_{2}\right) \times 100$

$\mathrm{C}_{1}$ : 絞り液の薬物濃度, $\mathrm{C}_{2}$ : 試料溶液の薬物濃 度

\section{結果及び考察}

脱脂綿にキトサンを吸着処理した表面処理脱脂 綿（絰素量 $0.006 \% ， 0.011 \% ， 0.016 \% ， 0.022 \%$ および $0.026 \%$ ）は日局脱脂綿と比較してわずか に黄色を帯びている以外は外観上の差はなく, 光 学顕微鏡 $(\times 100)$ でも形態上の差を認めなかっ た. また, 表面処理脱脂綿と日局脱脂綿の吸水量 は Table 1 に示すように有意差はなく，いずれも 日局脱脂綿の規格 $(100.0 \mathrm{~g}$ 以上)を満たしていた。 したがって,脱脂綿にキトサンを吸着処理しても， 脱脂綿の基本的な機能である吸水能力に影響は与 えないことを確認した。

この表面処理脱脂綿に対して，JIS L0217 106 法の繊維製品の水洗い方法に準じ，20倍量の液温 $30^{\circ} \mathrm{C}$ の水で 5 分間の摚拌洗浄を繰り返した. Fig. 1 に初期窒素量 $0.025 \%$ 表面処理脱脂綿の表面 処理量と洗浄回数の関係を示す. 水による洗浄で 
Table 1. Absorbency of J. P. Absorbent Cotton and Cotton Coated with Chitosan

\begin{tabular}{rc}
\hline \hline Materials & Weight of Water Absorbed $(\mathrm{g})$ \\
\hline J.P.Absorbent Cotton & $122.6 \pm 3.6$ \\
Cotton Coated with Chitosan & \\
[Nitrogen $0.006 \%$ ] & $123.5 \pm 2.7$ \\
[Nitrogen $0.011 \%$ ] & $123.0 \pm 3.6$ \\
[Nitrogen $0.016 \%$ ] & $120.8 \pm 2.1$ \\
[Nitrogen $0.022 \%]$ & $122.5 \pm 3.5$ \\
[Nitrogen $0.026 \%$ ] & $121.6 \pm 2.2$
\end{tabular}

Each value represents the mean \pm S.D. of 6 measurements.

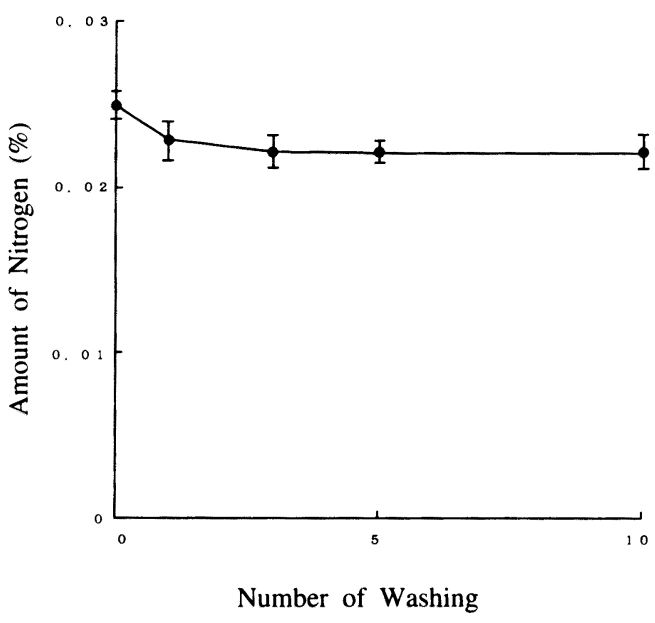

Fig. 1. Durability of Amount of Nitrogen for Washing in Cotton Coated with Chitosan

Each point represents the mean \pm S.D. of 3 measurements.

は，はじめの 3 回の洗浄で表面処理量は $12.0 \%$ 減 少したが, その後の洗浄ではほとんど変化せず, 水洗浄に対する堅ろう性は高いことが確認され た。

Fig. 2 にゼータ電位と表面処理量の関係を示 す. 負のゼータ電位を示す脱脂綿が, キトサンに よる表面処理が進むにしたがって電位が減少し， 更には正のゼータ電位に転位して増加していく傾 向が認められた。

これは, 正の電位を有するキトサンの吸着量が 増すに従い, 脱脂綿の負の電位が中和され, 更に

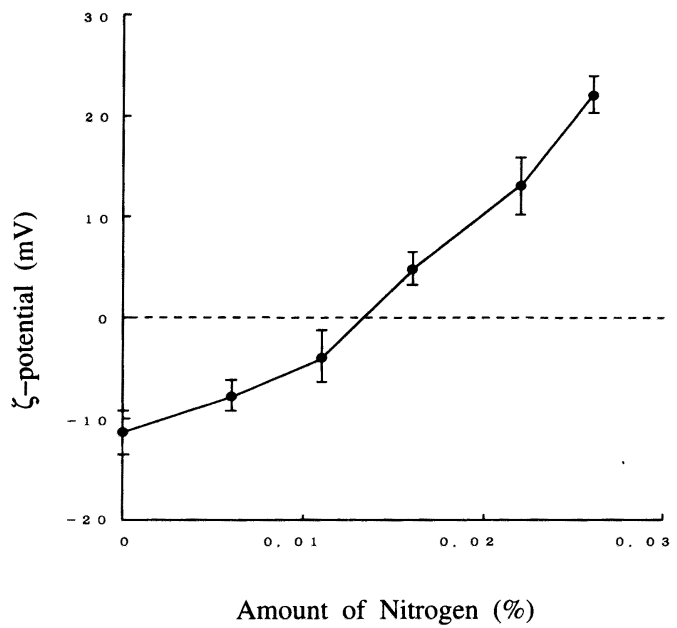

Fig. 2. Relationship between $\zeta$-Potential and Amount of Nitrogen in Cotton Coated with Chitosan (pH 6.0)

Each Point represents the mean \pm S.D. of 3 measurements.

吸着が進むことにより脱脂綿の負の電位に打ち勝 ち，正電位を示すためと考える。

また, Fig. 3に各薬物の吸着試験における回収 率と表面処理量の関係を示す. 表面処理量が増加 するに従って, カチオン性薬物の吸着量は減少 し, 窒素量 $0.026 \%$ 表面処理綿におけるグルコ ン酸クロルヘキシジン, 塩化ベンザルコニウムお よび塩酸ジブカインの回収率は未処理品に対して それぞれ24.4\%，40.9\%および39.2\%高まった。 一方, アニオン性薬物の吸着量はわずかに増加す 


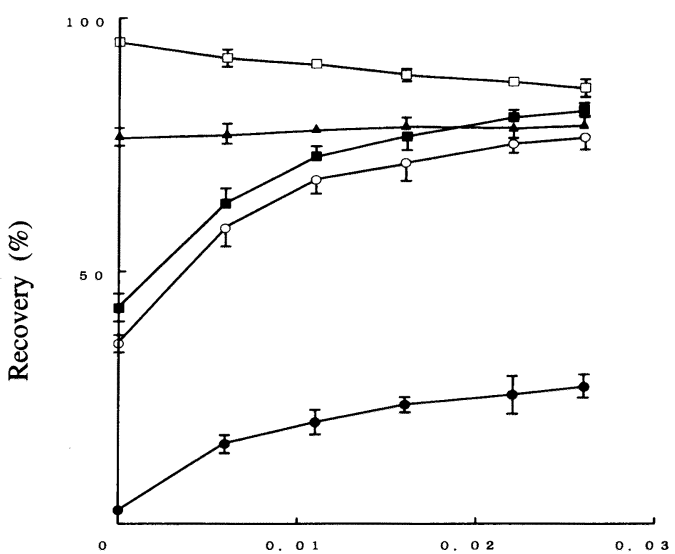

Amount of Nitrogen (\%)

Fig. 3. Relationship between Drug Adsorption and Amount of Nitrogen in Cotton Coated with Chitosan

Each Point represents the mean \pm S.D. of 3 measurements.

$: 0.05 \%$ chlorhexidine gluconate (pH 5.7),

$0: 0.05 \%$ benzalkonium chloride ( $\mathrm{pH} 6.1$ ),

口: $0.1 \%$ dibucaine hydrochloride ( $\mathrm{pH} 5.5$ ), $\square: 0.1 \%$ salicylic acid (pH 3.0), $\mathbf{\Delta}: 0.05 \%$ methyl paraoxybenzoate ( $\mathrm{pH}$ 6.1)

る傾向を示し, 窒素量0.026\%の表面処理綿にお けるサリチル酸の回収率は未処理品に対して 9.2\%低下した。なお，非イオン性薬物について は変化を認めなかった。 これらのことから，負の データ電位を示す脱脂綿にキトサンを吸着処理 し, 正のゼータ電位を付与することで, カチオン 性薬物との間の電気的反発力が寄与し, 吸着量が 減少しているものと考える。一方，アニオン性薬 物との間には電気的吸引力が働き, 吸着が進んだ ものと考える.

Fig. 4 に脱脂綿および表面処理脱脂綿のゼータ 電位と $\mathrm{pH}$ の関係を示す．脱脂綿では $\mathrm{pH}$ の低下 とともに脱脂綿に含まれる $\mathrm{COOH}$ 基の解離が抑 えられ，その負のゼータ電位は減少する傾向を示 している。 それに対し，表面処理脱脂綿ではアル カリ側では負のゼータ電位を示していたものの, 中性付近で正に転位し，その後の $\mathrm{pH}$ の低下とと もに正のゼータ電位は大きくなる傾向を示した。

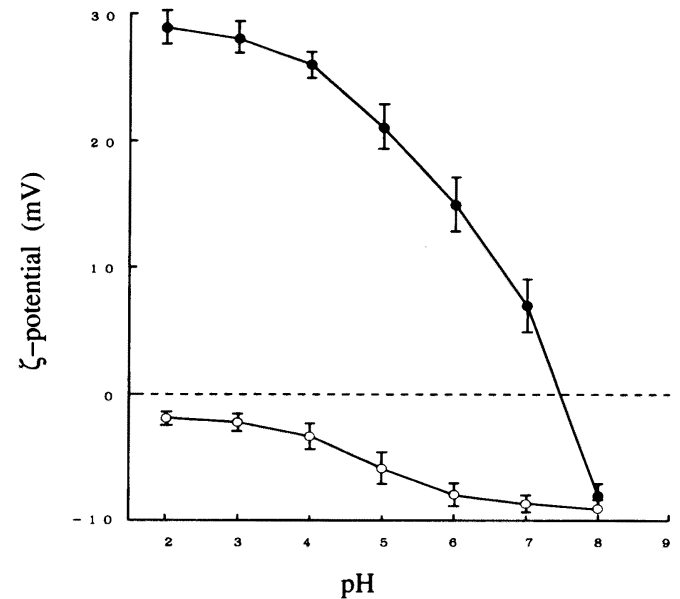

Fig. 4. Relationship between $\zeta$-Potential and $\mathrm{pH}$ in Various Cotton

Each Point represents the mean \pm S.D. of 3 measurements.

: J. P. Absorbent Cotton

: Cotton Coated with Chitosan (Amount of Nitrogen : $0.022 \%$ )

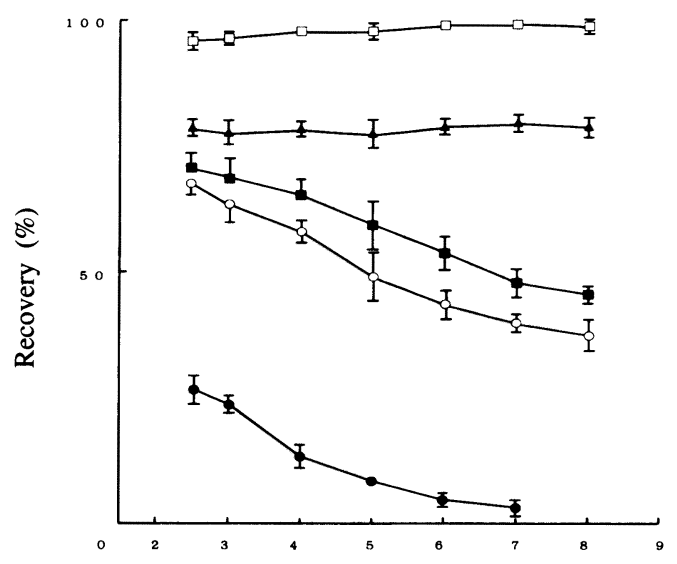

$\mathrm{pH}$

Fig. 5. Relationship between Drug Adsorption and $\mathrm{pH}$ in J. P. Absorbent Cotton

Each Point represents the mean \pm S.D. of 3 measurements.

: $0.05 \%$ chlorhexidine gluconate, $\bigcirc: 0.05 \%$ benzalkonium chloride, $\square: 0.1 \%$ dibucaine hydrochloride, $\square: 0.1 \%$ salicylic acid, $\Delta: 0.05 \%$ methyl paraoxybenzoate 


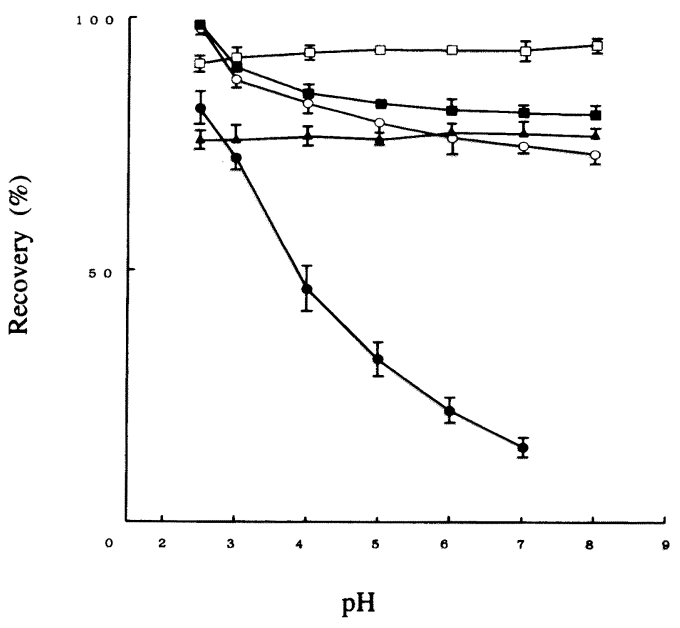

Fig. 6. Relationship between Drug Adsorption and $\mathrm{pH}$ in Cotton Coated with Chitosan (Amount of Nitrogen : $0.022 \%$ )

Each Point represents the mean \pm S.D. of 3 measurements.

: $0.05 \%$ chlorhexidine gluconate, $\bigcirc: 0.05 \%$ benzalkonium chloride, $\square: 0.1 \%$ dibucaine hydrochloride, $\square: 0.1 \%$ salicylic acid, $\Delta: 0.05 \%$ methyl paraoxybenzoate

これには $\mathrm{pH}$ の低下とともに脱脂綿に含まれる $\mathrm{COOH}$ 基の解離が抑えられるとともに，逆に吸 着処理されたキトサン中の $\mathrm{NH}_{2}$ 基の解離が進む ことによるものと考える.

Fig. 5 に脱脂綿, Fig. 6 に表面処理脱脂綿の $\mathrm{pH}$ と薬物吸着の関係を示す.いずれも $\mathrm{pH}$ が低 くなるに従って, カチオン性薬物では吸着量が少 なくなる傾向がみられたが，すべての $\mathrm{pH}$ の範囲 において表面処理脱脂綿の方が吸着が低いことが
判明した。これは $\mathrm{pH}$ の低下により脱脂綿では負 のゼータ電位が小さくなり，カチオン性薬物との 電気的吸引力が低下することにより吸着が低くな ると考えられるのに対し，表面処理脱脂綿では $\mathrm{pH}$ の低下によりゼータ電位が正に転位し，更に その正電位が大きくなっていくためにカチオン性 薬物との間で電気的反発力が働き，吸着がより抑 えられるためと考える.

アニオン性薬物および非イオン性薬物について はめだった変化はなかった。

以上, 脱脂綿にキトサンを吸着処理し，その吸 着特性を測定することにより脱脂綿へのカチオン 性薬物の吸着防止方法としての有用性について考 察した。

キトサンの吸着によって脱脂綿のゼータ電位は 負の電位から正の電位に転位し，その結果として カチオン性楽物の吸着が大きく抑えられ, 脱脂綿 にキトサンを吸着することが殺菌消毒剤等の外用 液剤に用いられる薬物に多いカチオン性薬物の吸 着防止に有効であることが認められた。

\section{引用文献}

1) 中東正晴, 野田明宏, 菊本桂子, 野間茂樹, 岩 尾勇, 病院薬学, 16, 81-55 (1990).

2）鈴木一市, 森田久代, 山添喜久夫, 川影逸郎, 藤井一郎, 病院薬学, 9, 339-342 (1983).

3) 梶本晴彦, 梅田恵津子, 薬剤学, 54, 129-134 (1994).

4) 須沢利郎, 工業化学雑誌, 62, 232-236 (1959).

5) 須沢利郎, 工業化学雑誌, 63, 148-151 (1960).

6) 須沢利郎, 向井徹雄, 工業化学雑誌, 73, 24512453 (1970). 